\title{
Feasibility of Lexicon Reading Materials of Labuhanbatu Utara Local Wisdom in Senior High School (SMAN) 1 Kualuh Selatan
}

\author{
Kursitasari $^{1}$, Khairil Ansari ${ }^{2}$, Evi Eviyanti ${ }^{2}$ \\ ${ }^{1}$ Master Student in State University of Medan (Unimed), Medan, Indonesia \\ ${ }^{2}$ Lecturer in State University of Medan (Unimed), Medan, Indonesia
}

\begin{abstract}
This study aims to discuss about feasibility of lexicon reading materials of Labuhanbatu Utara local wisdom in senior high school (SMAN) 1 Kualuh Selatan. The research location will be carried out in Labuhanbatu Utara regency precisely in Kualuh Selatan Sub-District consisting of twelve villages. The result shows that Labuhanbatu Utara's local wisdom lexicon is obtained based on six types of local wisdom, namely the quality of bordah kualuh art, endeng-endeng art, sinandong art, cenggok-cenggok tradition, mengupahupah tradition, and Labuhanbatu Utara's food. The six types of local wisdom above can be grouped into two types of arts and traditions. From the results of the research on noun lexicons there are 72 lexicons of all of Labuhanbatu Utara's local wisdom, and there are 45 lexicons from all the local wisdom of Labuhanbatu Utara.
\end{abstract}

Keywords : lexicon reading materials; Labuhanbatu Utara local wisdom; Senior High School (SMAN) 1 Kualuh Selatan

\section{Introduction}

Language environment is an environmental dimension that is physical and geographic which is the place of life for all languages and speakers. If a language is used by many speakers in many domains, that language will develop. Conversely, if a language that is used little by speakers in a narrow domain, the language will be eroded by a more dominant language. Continuity of this situation will continually lead to the extinction of the lexicon, especially with the release of new terms that replace even the displacement of the position of the old word or term. This happens due to the weakening of the form of the old lexicon.

One of them is the Kualuh Selatan sub-district, Gunting Saga village, which is currently using local languages, namely Malay and Batak. Local people use the language of the area while working and communicating with fellow workers. But the younger generation in the surrounding area rarely use the language around and is more dominant using Indonesian. This situation is the beginning of lexicon extinction, a shift in the meaning and extinction of certain lexicons. The traditions and culture of the surrounding community does not rule out the possibility of a shift towards various cultures. Culture that is once thick in the community will be lost with the entry of culture from the outside. Simanjuntak (2014: 32) states "the culture of indigenous peoples has advice, advice, teachings, even the rules of the human way of life in their fellow association, with people who are elder and appointed as leaders in relation to rights and obligations in relation to the natural environment, in relation to time, rain, heat, climate, etc. " Culture owned by Indonesian ethnic groups needs to be studied scientifically and deeply to know the cultural values they contain, to be developed in building the world of education. The thing stated by Simanjuntak is very true because one of the goals of education is to improve the culture itself. With the education that contains cultural values, the erosion of local culture and national culture can be avoided. Education itself will transfer culture and generation after generation. Local wisdom in the North Labuhanbatu area, namely the art of kualuh, endengendeng tradition, wages tradition, cenggok tradition, sinandong and culinary specialties of Labuhanbatu Utara. 
This wisdom manifests itself in the appreciation of local cultural heritage, along with the regeneration process in the local community so that the younger generation retains its cultural heritage. As an illustration of local wisdom that can be used as a student of coskata, namely the symbol of Labuhanbatu Utara. The symbol has the motto "Besimpul Strong Babontuk Elok", which means strong form and good appearance, another example;

hata pangupa (n) 'someone who becomes an elder in delivering exhorting advice or mangupah singer

indahan (n) 'white rice symbolizes sincerity, planning, and hard work.'

mamuncak (v) 'the martial arts scene that is usually found at the reception of the bride and groom, and guests.'

markobar (v) 'lecture or give advice.'

Along with socio-cultural changes the term will disappear, as a result the next generation no longer uses the local wisdom lexicon. Local wisdom is a view of life and science as well as a life strategy in the form of activity, carried out by local communities in answering various problems in meeting their needs. The importance of recognizing local wisdom for the local community is to recognize tradition and culture and maintain ecolinguistics as the identity of the people of Labuhanbatu Utara.

\subsection{Lexicon}

\section{Literature Review}

The Lexicon is a collection of lexemes in a language. The study of complexity includes what is meant by words, structuring vocabulary, word usage and storage, word learning, word evolution and word (etymology), inter-relationship, and word formation processes in a single phase. In everyday use, the lexicon is considered a synonym for cuneiform or vocabulary.

Sibarani (1997: 4) reveals "The lexicon includes components that contain all the information about words in a language such as semantic, syntactic, morphological, and phonological behavior, while the vocabulary is emphasized in the wealth of words that someone has or something language". According to Chaer (2007: 5) that the term lexicon comes from ancient Greek words which mean "words", "sayings", or "ways of speaking". The word lexicon like this is the same as lexeme, lexicography and lexical. So it can be concluded that the lexicon is lexeme in a language that includes words, speech and how to speak at a semantic level, syntactic, morphological, and phonological.

\subsection{Local Wisdom}

Understanding local wisdom consists of two words, namely wisdom and local. In general, local wisdom can be understood as local ideas that are wise, full of wisdom, good value that are embedded and followed by the community. According to Sibarani (2012: 122) revealed that:

Local wisdom is indigineous knowledge or local intelligence (genius) of a community that originates from the noble values of cultural traditions to regulate the level of people's lives in order to achieve community progress both in the creation of peace and the improvement of community welfare. Local wisdom may be in the form of local knowledge, local skills, local intelligence, local resources, local social processes, local ethics, and local customs.

Fajarini (2014: 123) "local wisdom as a view of life and science as well as tangible strategies of activities carried out by local communities in answering various problems in meeting their needs". The same thing was stated by Ridwan (in Handayani 2012: 17), it is 
knowledge that emerged from a long period that evolved together with the community and its environment in the local system that had been experienced together. The evolutionary process that is so long and inherent in society can make local wisdom a potential energy source from the community's collective knowledge system to live together dynamically and peacefully. This understanding sees local wisdom not only as a reference for one's behavior, but also further, namely being able to dynamize the life of a society full of civilization.

Based on this opinion, it can be concluded that local wisdom is an idea that arises and develops continuously in a community such as noble values, cultural traditions to regulate people's lives, progress, peace and improvement in people's welfare and is a local resource, local skills and local customs.

Type of local wisdom according to Sibarani, (2012: 133) containing cultural values include: (1) "welfare", (2) hard work, (3) discipline, (4) education, (5) health, (6) mutual cooperation, (7) gender management, (8) preservation and cultural creativity, (9) care for the environment, (10) "peace", (11) politeness, (12) honesty, (13) social solidarity, (14) harmony and conflict resolution, (15) commitment, (16) positive thoughts, and (gratitude )

\subsection{Ecolinguistic Theory}

Ecolinguistics is a scientific discipline that examines the environment and language. According to Mbete (2008: 1) "Ecolinguistics is an interdisciplinary language science, equating ecology and linguistics". In other terms, this study is also known as the term ecology. Actually there are four terms that refer to this study, namely linguisticecology, ecological linguistics, the ecology of language, and colinguistics (in al-Gayoni 2012: 24).

Meanwhile, in Indonesian the terms linguistic ecology, ecological linguistics, ecological language, and echinguistics are known. In other languages, also known the terms Ecologie deslangues / Ecologie du langage, Linguistique ecologique, Ecologie linguistique and Ecinguistique (French), Okologie der Sprache / sprachologie, Okologische Linguistics, Linguistics Ecology and Okolinguistics (Germany), and Ecologia des laslenguas, Ecologia linguistic and Ecolinguistica (Spanish).

In the Ecology of Language Shift, Fill (2001: 67) explains that basically ecology is a study of interdependence in a system. In language ecology, the concept of ecology combines environment, conservation, interaction, and systems in language. Ecolinguistics is the study of functional reciprocal relationships. The two parameters to be linked are language and environment. This depends on the perspective used in both ecological and ecological languages. The combination of the two results in ecolinguistic studies. Language ecology learns the support of various language systems that are introduced to the survival of living things, as well as the factors that affect the residence (place).

\subsection{Reading Materials}

Learning Indonesian at school is certainly inseparable from reading. Reading activity is very important for students because in the text contains useful values for students. Aryaningsih et al (2013: 2) stated that reading activities are very important for students because in the text contained values in the form of aesthetic values, and in their contents contained themes and mandates that are very beneficial for each student.

Understanding of reading material cannot be separated from the learning process. The process of learning a reading can be seen from the values obtained by students. Understanding the meaning of a reading is the main purpose of reading activity. In other words, when reading, the reader must also be able to understand the meaning and content of the reading. Choosing 
interesting reading is one of the tasks that must be done by the teacher. Interesting reading material will motivate students to read seriously and will support students' understanding. One interesting reading material is reading material that is easily understood by students, so reading is a fun activity and this is the purpose of the reading program.

\section{Research Methods}

The research location will be carried out in Labuhanbatu Utara regency precisely in Kualuh Selatan Sub-District consisting of twelve villages, namely (1) Bandar Lama Village (2) Damuli Kebun Village (3) Damuli Pekan Village (4) Gunting Saga Village, (5) Gunung Melayu Village (6) Hasang Village (7) Lobu Huala Village (8) Sialang Taji Village (9) Siamporik Village (10) Kelurahan Village (11) Simangalam Village and (12) Tanjung Pasir Village

The researchers chose Kualuh Selatan Subdistrict as the research location because (1) Kualuh Selatan Sub-district has a collection of local wisdom that is still preserved but the younger generation does not understand the local wisdom that is owned in the surrounding area. (2) Kualuh Selatan District still has a special culture, namely the culture of Kualuh.

Subsequent research was carried out in SMA 1 Kualuh Selatan located on the big road of Guntung Saga, Sidua-two village, Kualuh Selatan Subdistrict, Labuhanbatu Utara Regency, to measure students' understanding of lexicon nouns and Labuhanbatu Utara local wisdom verbs

\section{Discussion}

The feasibility of reading material is validated by material experts and design experts. After being validated, the product was tested in a limited field group and then revised to determine the feasibility of Labuhanbatu Utara's local wisdom lexicon reading material, the following data will be described as the validation of the feasibility test for reading material.

Validation of the product is intended to find out the opinions of material experts about the feasibility of content, the feasibility of presentation, and language. This validation was carried out by Dr. Wisman Hadi, S.Pd. M. Hum., And Dr. Tappil Rambe, S.Pd. M.Sc., were a lecturer at Medan State University. The assessment was carried out to obtain information on the quality of the reading material in order to improve the quality of lexicon reading materials of Labuhanbatu Utara local wisdom in senior high school (SMAN) 1 Kualuh Selatan. The results of the validation and assessment by the material expert in each aspect of the overall assessment are determined by the average score of each criterion. The results of the assessment are analyzed to determine whether or not the lexicon reading of Labuhanbatu Utara wisdom is appropriate. The average percentage of the assessment results by material experts is assessed based on aspects and indicators of assessment. Assessment carried out by material experts on reading material has four sub-components or aspects of assessment, namely the feasibility of content, the feasibility of presentation, the feasibility of the language and the feasibility of the book.

Based on the results of the assessment of the feasibility aspects of the material content that the Labuhanbatu Utara local wisdom lexicon reading material is stated as "Excellent" with a total average percentage of $89.84 \%$. Data from material expert validation on the feasibility of content can be seen in the table below. 
Table 1. Expert Assessment for Lexicon Reading Materials of Labuhanbatu Utara Local

Wisdom on the Aspect of Content Feasibility

\begin{tabular}{|c|c|c|c|}
\hline Sub Components & Assessment Indicator & $\begin{array}{l}\text { Average } \\
\text { Score }\end{array}$ & Criteria \\
\hline \multirow{2}{*}{$\begin{array}{l}\text { Conformity of } \\
\text { material with } \\
\text { cultural context in } \\
\text { student environment }\end{array}$} & $\begin{array}{l}\text { Completeness of language } \\
\text { material and rules }\end{array}$ & 87,5 & Excellent \\
\hline & Material breadth & 87,5 & Excellent \\
\hline \multirow[t]{7}{*}{ Material accuracy } & $\begin{array}{l}\text { The accuracy of the concept } \\
\text { and the definition of } \\
\text { Labuhanbatu Utara local } \\
\text { wisdom }\end{array}$ & 87,5 & Excellent \\
\hline & Accuracy of facts and data & 87,5 & Excellent \\
\hline & $\begin{array}{l}\text { Accuracy of examples and } \\
\text { cases }\end{array}$ & 87,5 & Excellent \\
\hline & $\begin{array}{l}\text { Accuracy of images, diagrams } \\
\text { and illustrations }\end{array}$ & 87,5 & Excellent \\
\hline & Accuracy of terms & 87,5 & Excellent \\
\hline & $\begin{array}{l}\text { Accuracy of notations, symbols } \\
\text { and icons }\end{array}$ & 87,5 & Excellent \\
\hline & Accuracy of references & 87,5 & Excellent \\
\hline \multirow[t]{5}{*}{ Material Update } & $\begin{array}{l}\text { Compatibility of material with } \\
\text { the development of science }\end{array}$ & 87,5 & Excellent \\
\hline & $\begin{array}{l}\text { Showing the topic of } \\
\text { Labuhanbatu Utara's local } \\
\text { wisdom }\end{array}$ & 100 & Excellent \\
\hline & $\begin{array}{l}\text { Pictures, diagrams and } \\
\text { illustrations in everyday life }\end{array}$ & 100 & Excellent \\
\hline & $\begin{array}{l}\text { Use examples of cases found in } \\
\text { everyday life }\end{array}$ & 100 & Excellent \\
\hline & Library update & 87,5 & Excellent \\
\hline \multirow[t]{2}{*}{ Encourage curiosity } & Encourage curiosity & 87,5 & Excellent \\
\hline & Creating the ability to ask & 87,5 & Excellent \\
\hline \multicolumn{2}{|l|}{ Average } & 89,84 & Excellent \\
\hline
\end{tabular}

The material expert assesses the Labuhanbatu North wisdom lexicon reading material with content eligibility with an average score of $89.84 \%$ with the criteria of "Excellent". The average percentage results from the content feasibility aspects of the sub-component of the material suitability assessment with the cultural context in the student environment, material accuracy, material proficiency and encouraging curiosity, can be seen in the following table.

Table 2. Expert Assessment for Material of Aspects of Content Feasibility

\begin{tabular}{|c|l|c|c|}
\hline No. & \multicolumn{1}{|c|}{ Sub-Components } & $\begin{array}{c}\text { Average } \\
\text { Score }\end{array}$ & Criteria \\
\hline 1 & $\begin{array}{l}\text { Conformity of material with cultural } \\
\text { context in student environment }\end{array}$ & 87,5 & Excellent \\
\hline 2 & Material accuracy & 87,5 & Excellent \\
\hline
\end{tabular}




\begin{tabular}{|c|l|c|c|}
\hline 3 & Material Update & 95 & Excellent \\
\hline 4 & Encourage Curiosity & 87,5 & Excellent \\
\hline Average & $\mathbf{8 9 , 3 7}$ & Excellent \\
\hline
\end{tabular}

Based on the results of the percentage of material experts about the feasibility of the content above, it was found that the sub-component of the appraisal of material suitability with the cultural context in the students had an average percentage of $87.5 \%$, the accuracy of the material with an average of $87.5 \%$. average of $95 \%$ and encourage curiosity with an average of $87.5 \%$. The results of the average percentage of all sub-components of the assessment of the content feasibility aspect are $89.37 \%$ with the criteria of "Excellent".

Furthermore, the results of the material validation data on the feasibility of presentation. The assessment of the feasibility aspect of presentation according to material experts was assessed as "Excellent" with a total percentage of $91.66 \%$. The data from the material validation expert have the feasibility of presentation can be seen in the following table.

Table 3. Expert Materials Assessment of Lexicon Reading Materials of Labuhanbatu Utara Local Wisdom on Aspects of Feasibility of Presentation

\begin{tabular}{|c|c|c|c|}
\hline $\begin{array}{c}\text { Sub- } \\
\text { Components }\end{array}$ & Assessment Indicator & $\begin{array}{l}\text { Average } \\
\text { Score }\end{array}$ & Criteria \\
\hline \multirow[t]{2}{*}{$\begin{array}{l}\text { Presentation } \\
\text { Techniques }\end{array}$} & $\begin{array}{l}\text { Systematic consistency of presentation in } \\
\text { learning activities as enrichment of } \\
\text { vocabulary of students in high school }\end{array}$ & 87,5 & Excellent \\
\hline & Creed concept & 87,5 & Excellent \\
\hline \multirow[t]{3}{*}{ Learning Support } & Involvement of students & 87,5 & Excellent \\
\hline & Student-centered & 87,5 & Excellent \\
\hline & $\begin{array}{l}\text { Train students' ability to solve problems } \\
\text { through illustrations }\end{array}$ & 87,5 & Excellent \\
\hline \multirow{4}{*}{$\begin{array}{l}\text { Presentation } \\
\text { Completeness }\end{array}$} & Preface & 87,5 & Excellent \\
\hline & Table of Contents & 100 & Excellent \\
\hline & Glossary & 100 & Excellent \\
\hline & References & 100 & Excellent \\
\hline \multicolumn{2}{|l|}{ Average } & 91,66 & Excellent \\
\hline
\end{tabular}

In the aspect of the feasibility of presentation, the material expert assessed that the reading material in the form of lexicon handout from Labuhanbatu Utara local wisdom had a percentage of $91.66 \%$, with the criteria of "Excellent". The results of the average percentage of the feasibility aspect of the presentation of the sub-components of the assessment of presentation techniques, supporting learning and presentation are shown in the table below.

Table 4. Expert Materials Assessment of the Feasibility Aspects of Presentation

\begin{tabular}{|c|c|c|c|}
\hline No. & Sub-Components & $\begin{array}{c}\text { Average } \\
\text { Score }\end{array}$ & Criteria \\
\hline 1 & Presentation Techniques & 87,5 & Excellent \\
\hline
\end{tabular}




\begin{tabular}{|c|l|c|c|}
\hline 2 & Learning Support & 87,5 & Excellent \\
\hline 3 & Presentation Completeness & 96,87 & Excellent \\
\hline & Average & $\mathbf{9 0 , 6 2}$ & Excellent \\
\hline
\end{tabular}

Based on the feasibility table presented above, it was obtained that the sub-component of the assessment of presentation techniques had an average percentage of $87.5 \%$, supporting learning had an average percentage of $87.5 \%$ and the completeness of presentation had an average of $96.87 \%$. The results of the average percentage of the overall components of the assessment of the feasibility aspect of presentation are $90.62 \%$ with the criteria of "Excellent".

Furthermore, in the aspect of language assessment, the material expert assessed that the reading material in the form of lexicon handouts from the local wisdom of Labuhanbatu Utara had language feasibility with an average percentage of $87.5 \%$, with the criteria of "Excellent". Data on the results of material expert validation on aspects of language feasibility can be seen in the following table.

Table 5. Expert Material Assessment of Lexicon Reading Materials of Labuhanbatu Utara Local Wisdom on Aspects of Language Feasibility

\begin{tabular}{|c|c|c|c|}
\hline $\begin{array}{c}\text { Sub- } \\
\text { Components }\end{array}$ & Assessment Indicator & $\begin{array}{c}\text { Average } \\
\text { Score }\end{array}$ & Criteria \\
\hline \multirow{3}{*}{ Straightforward } & Accuracy of sentence structure & 87,5 & Excellent \\
\hline & Effectiveness of sentences & 87,5 & Excellent \\
\hline & Stiffness of terms & 87,5 & Excellent \\
\hline \multirow{2}{*}{ Communicative } & Message readability & 87,5 & Excellent \\
\hline & Accuracy of language use & 87,5 & Excellent \\
\hline \multirow{2}{*}{$\begin{array}{l}\text { Dialogical and } \\
\text { interactive }\end{array}$} & $\begin{array}{l}\text { The ability to motivate messages or } \\
\text { information }\end{array}$ & 87,5 & Excellent \\
\hline & The ability to encourage critical thinking & 87,5 & Excellent \\
\hline \multicolumn{2}{|l|}{ Average } & 87,5 & Excellent \\
\hline
\end{tabular}

The results of the average percentage of aspects of language feasibility assessment from straightforward, communicative, dialogical and interactive sub-components can be seen in the following table.

Table 6. Material Expert Assessment of Language Feasibility Aspects

\begin{tabular}{|c|l|c|c|}
\hline No. & \multicolumn{1}{|c|}{ Sub-Components } & $\begin{array}{c}\text { Average } \\
\text { Score }\end{array}$ & Criteria \\
\hline 1 & Straightforward & 87,5 & Excellent \\
\hline 2 & Communicative & 87,5 & Excellent \\
\hline 3 & Dialogical and interactive & 87,5 & Excellent \\
\hline & Average & $\mathbf{8 7 , 5}$ & Excellent \\
\hline
\end{tabular}

Based on the results of the assessment by material experts on the assessment of the feasibility of the language above, it was obtained that the sub-component of the assessment of the innocence had an average percentage of $87.50 \%$, communicative had an average percentage of $87.50 \%$, dialogic and interactive had an average percentage of $87.50 \%$. The results of the 
average percentage of the entire sub-component of the assessment of language feasibility aspects are $87.50 \%$ with the criteria of "Excellent".

Furthermore, in the aspect of book feasibility assessment, material experts assessed that the reading material in the form of lexicon handouts from Labuhanbatu Utara local wisdom had book eligibility with an average percentage of $87.50 \%$, with the criteria of "Excellent". From the results of the material validation experts on the aspects of book feasibility can be seen in the following table.

Table 7. Material Expert Assessment of Lexicon Reading Materials of Labuhanbatu Utara Local Wisdom on Aspects of Book Feasibility

\begin{tabular}{|l|l|c|c|}
\hline \multicolumn{1}{|c|}{$\begin{array}{c}\text { Sub- } \\
\text { Components }\end{array}$} & \multicolumn{1}{|c|}{ Assessment Indicator } & $\begin{array}{c}\text { Average } \\
\text { Score }\end{array}$ & Criteria \\
\hline $\begin{array}{l}\text { Conformity with } \\
\text { the level of } \\
\text { development of } \\
\text { students }\end{array}$ & $\begin{array}{l}\text { Conformity of students' intellectual } \\
\text { development }\end{array}$ & 87,5 & Excellent \\
\cline { 2 - 5 } & $\begin{array}{l}\text { Conformity with the level of emotional } \\
\text { development of students }\end{array}$ & 87,5 & Excellent \\
\hline $\begin{array}{l}\text { Allegiance and } \\
\text { integration of } \\
\text { the mindset }\end{array}$ & $\begin{array}{l}\text { Allegiance and integration between learning } \\
\text { activities }\end{array}$ & 87,5 & Excellent \\
\cline { 2 - 5 } $\begin{array}{l}\text { Use of terms, } \\
\text { symbols and } \\
\text { icons }\end{array}$ & Consistency in the use of terms & 87,5 & Excellent \\
\cline { 2 - 5 } & Consistency of using symbols or icons & 87,5 & Excellent \\
\hline Average & & $\mathbf{8 7 , 5}$ & Excellent \\
\hline
\end{tabular}

The average percentage results with aspects of the assessment of book feasibility from the sub-components of conformity with the level of development of students, the chaos and integration of the flow of thought and the use of terms, symbols and icons can be seen in the following table.

Table 8. Assessment of Material Experts on Aspects of Feasibility of Books

\begin{tabular}{|c|l|c|l|}
\hline No. & \multicolumn{1}{|c|}{ Sub-Components } & $\begin{array}{c}\text { Average } \\
\text { Score }\end{array}$ & Criteria \\
\hline 1 & $\begin{array}{l}\text { Conformity with the level } \\
\text { of development of students }\end{array}$ & 87,5 & Excellent \\
\hline 2 & $\begin{array}{l}\text { Allegiance and integration } \\
\text { of the mindset }\end{array}$ & 87,5 & Excellent \\
\hline 3 & $\begin{array}{l}\text { Use of terms, symbols and } \\
\text { icons }\end{array}$ & 87,5 & Excellent \\
\hline Average & $\mathbf{8 7 , 5}$ & Excellent \\
\hline
\end{tabular}

Based on the results of the assessment of material experts about the feasibility assessment of the book above, it was found that the sub-component of the assessment of conformity with the level of development of students had an average percentage of $87.50 \%$, intrusion and integration of thought flow had an average percentage of $87.50 \%$ and usage terms, symbols and icons have an average percentage of $87.50 \%$. The results of the average percentage of the entire sub-component of the assessment of the book feasibility aspect are $87.50 \%$, with the 
criteria of "Excellent". Based on the results of the validation from the material experts, this reading material has been used as a reading material in the form of lexicon handouts of Labuhanbatu Utara local wisdom.

Suggestions from material expert validators both in writing and verbally are generally listed in the table below.

Table 9. Suggestions from the Material Validator

\begin{tabular}{|c|l|}
\hline No. & Suggestions \\
\hline 1 & $\begin{array}{l}\text { In general this reading material is quite good, but it should be further } \\
\text { refined. }\end{array}$ \\
\hline 2 & Enrich the literature. \\
\hline 3 & Handout design clarified \\
\hline
\end{tabular}

Design experts validate reading material products in the form of lexicon handouts from Labuhanbatu Utara local wisdom. This design validation was carried out by Dr. Surya Masniari Hutagalung, S.Pd., M.Pd., and Dr. Daulat Saragi, M. Hum., are lecturer at Medan State University. An assessment of the design aspects was carried out to improve the quality of the reading material. The results of the validation of reading material by design experts concluded that the learning design made was in the criteria of "Excellent" with a total percentage of 93.33\%. Data from the design expert validation can be seen in the table below.

Table 10. Scores for Material Design Experts Assessment of Lexicon Labuhanbatu Utara Wisdom

\begin{tabular}{|c|c|c|c|}
\hline $\begin{array}{c}\text { Sub- } \\
\text { Component }\end{array}$ & Assessment Indicator & $\begin{array}{l}\text { Average } \\
\text { Percentage }\end{array}$ & Criteria \\
\hline \multirow{2}{*}{$\begin{array}{l}\text { Size of } \\
\text { Reading } \\
\text { Material } \\
\text { Handouts } \\
\end{array}$} & $\begin{array}{l}\text { Size compliance with standards ISO } 216 \text { (A4, A5, } \\
\text { dan B5) }\end{array}$ & 100 & Excellent \\
\hline & Suitability of size with material content & 100 & Excellent \\
\hline \multirow{9}{*}{$\begin{array}{l}\text { Cover } \\
\text { Handout } \\
\text { Design } \\
\text { Cover } \\
\text { Material }\end{array}$} & $\begin{array}{l}\text { Appearance of elements of the layout on the front, } \\
\text { back and back cover harmoniously has a rhythm } \\
\text { and unity and consistency }\end{array}$ & 100 & Excellent \\
\hline & Good display of center of view (center point) & 87,5 & Excellent \\
\hline & $\begin{array}{l}\text { The color elements of the layout are harmonious } \\
\text { and clarify the function }\end{array}$ & 87,5 & Excellent \\
\hline & $\begin{array}{l}\text { The composition and size of the layout (title, } \\
\text { author, illustration, logo, etc.) is proportional, } \\
\text { balanced, and in line with the layout of the } \\
\text { contents (according to the pattern) }\end{array}$ & 100 & Excellent \\
\hline & \multicolumn{3}{|l|}{ The letters used are interesting and easy to read } \\
\hline & $\begin{array}{l}\text { The font size of the reading material for the } \\
\text { handout is more dominant and proportional than } \\
\text { the size of the author's name }\end{array}$ & 100 & Excellent \\
\hline & $\begin{array}{l}\text { The reading material's handout title color } \\
\text { contrasts with the background color }\end{array}$ & 100 & Excellent \\
\hline & Do not use too many font combinations & 100 & Excellent \\
\hline & \multicolumn{3}{|l|}{ Illustration of Cover Material } \\
\hline
\end{tabular}




\begin{tabular}{|c|c|c|c|}
\hline & $\begin{array}{l}\text { Describe the content / material of handout reading } \\
\text { material and reveal the character of the object }\end{array}$ & 100 & Excellent \\
\hline & $\begin{array}{l}\text { Shape, color, size, proportion of objects according } \\
\text { to reality }\end{array}$ & 100 & Excellent \\
\hline \multirow{21}{*}{$\begin{array}{l}\text { Design of } \\
\text { the contents } \\
\text { of the } \\
\text { reading } \\
\text { material }\end{array}$} & \multicolumn{3}{|l|}{ Layout Consistency } \\
\hline & $\begin{array}{l}\text { Layout element layout is consistent based on } \\
\text { patterns }\end{array}$ & 75 & Good \\
\hline & Separation between paragraphs is clear & 87,5 & Excellent \\
\hline & Printing area and proportional margin & 87,5 & Excellent \\
\hline & The page margins are side by side proportional & 87,5 & Excellent \\
\hline & $\begin{array}{l}\text { Spaces between text and illustrations are } \\
\text { appropriate }\end{array}$ & 87,5 & Excellent \\
\hline & $\begin{array}{l}\text { The placement of each handout title for page / } \\
\text { folio reading material is correct }\end{array}$ & 87,5 & Excellent \\
\hline & $\begin{array}{l}\text { The placement of illustrations and captions is } \\
\text { appropriate }\end{array}$ & 100 & Excellent \\
\hline & $\begin{array}{l}\text { Placement of decoration / illustration as } \\
\text { background does not interfere with title, page } \\
\text { number text }\end{array}$ & 100 & Excellent \\
\hline & $\begin{array}{l}\text { The placement of titles, subtitles, illustrations, } \\
\text { and captions does not interfere with } \\
\text { understanding }\end{array}$ & 100 & Excellent \\
\hline & Do not use too many fonts & 100 & Excellent \\
\hline & $\begin{array}{l}\text { The use of letter variations (bold, italic, all } \\
\text { capital, small capital) is not excessive }\end{array}$ & 87,5 & Excellent \\
\hline & Normal text width & 87,5 & Excellent \\
\hline & Spaces between lines of normal text arrangement & 87,5 & Excellent \\
\hline & Normal inter-letter spacing (kerning) & 87,5 & Excellent \\
\hline & $\begin{array}{l}\text { The hierarchy of titles is clear, consistent and } \\
\text { proportional }\end{array}$ & 87,5 & Excellent \\
\hline & Hyphenation sign & 87,5 & Excellent \\
\hline & Illustration Contents & & \\
\hline & $\begin{array}{l}\text { Able to express the meaning / meaning of the } \\
\text { object }\end{array}$ & 100 & Excellent \\
\hline & $\begin{array}{l}\text { Accurate and proportional forms in accordance } \\
\text { with reality }\end{array}$ & 100 & Excellent \\
\hline & Creative and dynamic & 87,5 & Excellent \\
\hline \multicolumn{2}{|l|}{ Average } & $\mathbf{9 3 , 3 3}$ & Excellent \\
\hline
\end{tabular}

Design experts assess the reading material in the form of lexicon handouts from Labuhanbatu Utara local wisdom has a feasibility with a score of $93.33 \%$. The average percentage results obtained based on the assessment sub-components in the form of reading material size handouts, cover design handouts reading material and design content of reading material handouts, this can be seen in table 11 below. 
Table 11. Assessment of Designers

\begin{tabular}{|c|l|c|c|}
\hline No. & \multicolumn{1}{|c|}{ Sub-Component } & $\begin{array}{c}\text { Average } \\
\text { Score }\end{array}$ & Criteria \\
\hline 1 & Size of reading material handouts & 100 & Excellent \\
\hline 2 & Cover design of handout reading material & 97,22 & Excellent \\
\hline 3 & Design the contents of the reading material handouts & 90,78 & Excellent \\
\hline \multicolumn{2}{|l|}{ Average } & $\mathbf{9 6 , 0 0}$ & Excellent \\
\hline
\end{tabular}

Based on the results of the average percentage addressed in the table above, it was found that the sub-component of the assessment of reading material size had an average percentage of $100 \%$, the cover design of the handout material had an average percentage of $97.22 \%$ and the design content reading material handouts have a percentage of $90.78 \%$. The results of the average percentage of the overall sub-component assessment of the feasibility of reading material design are $96.00 \%$ with the criteria of "Excellent". This means that the reading material in the form of lexicon handouts from Labuhanbatu Utara local wisdom is appropriate to use.

\section{Conclusion}

Labuhanbatu Utara's local wisdom lexicon is obtained based on six types of local wisdom, namely the quality of bordah kualuh art, endeng-endeng art, sinandong art, cenggokcenggok tradition, mengupah-upah tradition, and Labuhanbatu Utara's food. The six types of local wisdom above can be grouped into two types of arts and traditions. From the results of the research on noun lexicons there are 72 lexicons of all of Labuhanbatu Utara's local wisdom, and there are 45 lexicons from all the local wisdom of Labuhanbatu Utara.

The product feasibility in the form of Labuhanbatu Utara's local wisdom lexicon handout for high school class $11^{\text {th }}$ students is eligible and suitable for use as individual reading material, based on the assessment of material experts, and design experts. The results of the material expert validation included content eligibility with an average of $89.84 \%$ on excellent criteria, the feasibility of presentation with an average of $91.66 \%$ on excellent criteria, aspects of language with an average of $87.5 \%$ on excellent criteria, book feasibility aspects with an average of $87.5 \%$ on excellent criteria and the results of the validation of learning design experts with an average of $93.33 \%$ on excellent criteria.

\section{References}

Adisaputera, Abdurahman. (2009). Potensi Kepunahan Bahasa Pada Komunitas Melayu Langkat di Stabat, Kabupaten Langkat, Sumatera Utara. Jurnal Logat Volume V No. 1 April 2009. Medan: Universitas Sumatera Utara. pp.45-55.

Albertus, D.K. 2010. Pendidikan Karakter, Strategi Pendidikan Anak di Zaman Global. Jakarta: Grasindo.

Alwi, Dardjowidjojo, Lapoliwa, dan Moeliono. 1993. Tata Bahasa Baku Bahasa Indonesia. Jakarta: Departemen Pendidikan dan Kebudayaan Republik Indonesia. 
Budapest International Research and Critics in Linguistics and Education (BirLE) Journal

Volume 2, No 3, August 2019, Page: 454-467

e-ISSN: 2655-1470 (Online), p-ISSN: 2655-2647 (Print)

www.bircu-journal.com/index.php/birle

emails: birle.journal@gmail.com

birle.journal.qa@gmail.com

Al-Gayoni, Yusradi Usman. (2010). Penyusutan Tutur dalam Masyarakat Gayo: Pendekatan Ekolinguistik. Tesis. Medan: Sekolah Pascarjana USU. 2012. Ekolinguistik. Jakarta: Pang Linge Bekerjasama dengan Research Center for Gayo (RCfG).

Amri, Yusni Khairul. (2011). Tradisi Lisan Upacara Perkawinan Adat Tapanuli Selatan (Pemahaman Leksikon pada Remaja di Padang Sidempuan). Tesis. Medan: Universitas Sumatera Utara.

Arikunto, Suharsimi. 2006. Metode Penelitian Kualitatif. Jakarta: Bumi Aksara 2003. Prosedur Penelitian Suatu Pendekatan. Jakarta: Rineka Cipta.

Aryaningsih, dkk. (2013). Pengembangan Bahan Ajar Membaca Sastra Indonesia dan Perangkat Penilaian Autentik Siswa Kelas VII Semester I SMP Negeri 8 Denpasar.

Jurnal Program Pascasarjana Universitas Pendidikan Ganesha. Denpasar. UPG. 40-52.

Bintz, William. P. (2011). Teaching Vocabulary Across The Curriculum. Middle School Journal. pp. 44-53.

Cahyono, Bambang Yudi. (2008). The Teaching Of EFL Vocabulary in The Indonesian Context The State of The Art. TEFLIN Journal, Vol. 19. No. 1. Hlm 1-17.

Chaer, Abdul. 2006. Tata Bahasa Praktis Bahasa Indonesia. [edisi revisi]. Jakarta: Rineka Cipta. 2007. Leksikologi dan Leksikografi Indonesia. Jakarta: RinekaCipta.

Chomsky, Noam. 2000. New Horizon in the Study of Language and Mind. Cambridge: Cambridge University Press.

Crystal, David. 2008. A Dictionary of Linguistics and Phonetics 6 Edition. United Kigdom: Blackwell Publishing.

Dalman. 2013. Keterampilan Membaca. Jakarta: Raja Grafindo Persada.

Denzin dan Lincoln. 2009. Handbook of Qualitative Research. Yogyakarta: Pustaka Pelajar. (Translated by Dariyatno, Fata, Abi, dan Rinaldi).

Fajarini, U. 2014. Peranan Kearifan Lokal Dalam Pendidikan Karakter. Universitas Islam Negeri ( UIN). Jakarta. Diakses pada tanggal 20 October 2018.

Fill, Alwin and Peter Mühlhäusler. 2001. The Ecolinguistics Reader Language,Ecology and Environment. London: Continuum.

Handayani, Dona. (2012). Tradisi Ritual Lukah Gilo pada Masyarakat Suku Boai Provinsi Riau. Tesis. Medan. Universitas Sumatera Utara.

Haugen, Einar. (1972). "The Ecology of Language”. The Ecology of Language. Ed.Anwar S. Dil. California: Stanford University. 325-339.

Harjanto. 2006. Perencanaan Pengajaran. Jakarta: Bumi Aksara.

Jabrohim. 2001. Metodologi Penelitian Sastra. Yogyakarta: Hanindita Graha Widya.

Kaldum, Muhammad Ibnu. 2016. Tingkat Keterbacaan Wacana Nonfiksi pada Buku Teks Bahasa Indonesia Pegangan Siswa SMA Kelas X Kurikulum 2013 dengan Menggunakan Metode Grafik Fry. Jurnal Humanika (online). Volume 16, Nomor 1, (http://ojs.uho.ac.id, diakses 18 Maret 2019).

Koentjaraningrat. 2009. Pengantar Ilmu Antropologi. Jakarta: PT.Rineka Cipta.

Kusmarwanti, dkk. (2012). Pengembangan Model Pembinaan Menulis Karya Sastra bagi Anak dan Remaja. Jurnal Fenolingua. Diakses tanggal 30 Maret 2019.

Lindo, AnnaVibeke dan Jeppe Bundsgaard. (2000). Dialectical Ekolinguistics Three Essays for the Symposium 30 Years of Language and Ecology in Graz December 2000.

Austria: University of Odense Research Group for Ecology, Language and Ecology.

Mahsun. 2005. Metode Penelitian Bahasa. Jakarta: Raja Grafindo Persada. 
Budapest International Research and Critics in Linguistics and Education (BirLE) Journal

Volume 2, No 3, August 2019, Page: 454-467

e-ISSN: 2655-1470 (Online), p-ISSN: 2655-2647 (Print)

www.bircu-journal.com/index.php/birle

emails: birle.journal@gmail.com

birle.journal.qa@gmail.com

Majid, Abdul. 2011. Perencanaan Pembelajaran Mengembangkan Standar Kompetensi Guru. Bandung: PT Remaja Rosdakarya

Mbete, Aron Meko. (2002). Ungkapan-ungkapan Dalam Bahasa Lio dan Fungsinya dalam Melestarikan Lingkungan. Jurnal Linguistika, Vol. 19

No. 17, September 2002. Bali: Udayana.

(2008). Problematika Keetnikan dan Kebahasaan dalam Persfektif Ekolinguistik.

Disampaikan dalam Seminar Nasional Budaya Etnik III, Diselenggarakan oleh USU.

Diakses tanggal 5 desember 2018.

Moleong, Lexy J. 2014. Metodologi Penelitian Kualitatif. Bandung: PT. Remaja Rosdakarya. 2006. Metodologi Penelitian Kualitatif. [Edisi Revisi]Bandung: Rosdakarya.

Mukarto, F.X. (2005). Assessing the Depth of Second Language Vocabulary Knowledge. Singapore: Presented at the 38th RELC Internasional Seminar. SEAMEO Regional Language Centre. Vol. 8. No. 3. pp. 152-169.

Mulyani, Mimi (2012). Model Pembelajaran Menulis Berbasis Kearifan Lokal yang Berorientasi Pendidikan Karakter. Diakses dari http://www.jurnalpena.com/index.php/artikel/55-model pembelajaranmenulis-berbasiskearifan-lokal-yang-berorientasi-pendidikan-karakter. Diakses tanggal 5 desember 2018.

Nation, I.S.P. (2002). Best Practice in Vovabulary Teaching and Learning. Dalam J.C. Richards \& W.A. Renandya (Eds) Metodology in Language Teaching: an Anthology of Current Practice. Cambridge University Press. (2006). How Large a Vocabulary is Needed for Reading and Listening. The Canadian Modern Language Review/ La Revue Cannadienne des langues vivantes. Vol. 63. No. 1. pp. $60-82$

Nunan, David. 1991. Language Teaching Methodology. New York: Prentice-Hall. Inc.

Nurgiyantoro, Burhan. 2010. Penilaian Pembelajaran Bahasa Berbasis Kompetensi. Yogyakarta: BPFE- Yogyakarta.

Oxford, Rebecca dan David Crookall. (1990). Vocabulary Learning: A Critical Analysis of Techniques. Test Canada Journal/ Revue TesI Du Canada. Vol. 7. No. 2. pp.9-30.

Palmer, F.R. 1976. Semantics a New Outline. Cambridge University.

Prastowo, Andi. 2015. Panduan Kreatif Membuat Bahan Ajar Inovatif. Yogyakarta: DIVA Press.

Pradopo, Rachmat Djoko. 2011. Beberapa Teori Sastra, Metode Kritik, dan Penerapannya. Yogyakarta: Pustaka Pelajar.

Pramesti, Utami Dewi. (2015). Peningkatan Pengusaan Kosakata Bahasa Indonesia dalam Keterampilan Membaca Melalui Teka-teki Silang. Jurnal Puitika. Volume 11. No. 1. pp 82-93

Rasna, I Wayan. (2010). Pengetahuan dan Sikap Remaja Terhadap Tanaman Obat Tradisional di Kabupaten Buleleng dalam Rangka Pelestarian Lingkungan: Sebuah Kajian Ekolinguistik. Jurnal Bumi Lestari. Volume 10 No. 2. 321-332.

Ratna, Nyoman Kutha. 2005. Sastra dan Cultural Studies. Yogyakarta: Pustaka Pelajar. . 2007. Teori, Metode, dan Teknik Penelitian Sastra. Yogyakarta: Pustaka Pelajar.

Richards, Jack C. dan Willy A Renandya. 2002. Methodology in Language Teaching: An Anthology of Current Practice. New York: Cambridge University Press.

Ricklefs, Robert E. 1976. The Economy of Nature A Textbook in Basic Ecology. New York: Chiron Press Incorporated. 
Robihim. (2008). Analisis Metode Belajar Kosakata. Lingua Cultura. Vol. 2. No. 2. pp. 188203.

Saebani, Beni Ahmad dan Affidudin. 2012. Metodologi Penelitian Kualitatif. Bandung: Pustaka Setia.

Sibarani, Robert. 1997. Leksikografi. Medan: USU Press. 2012. Kearifan Lokal. Jakarta: Asosiasi Tradisi Lisan (ATL).

Subroto, Edi D. 1992. Pengantar Metode Penelitian Linguistik Struktural. Surakarta: UNS Press.

Subiyanto, Agus. 2008. Ekolinguistik dan Model Penerapannya. Diponegoro: Universitas Diponegoro.

Sudaryanto. 1993. Metode dan Aneka Teknik Analisis Bahasa Pengantar Penelitian Wahana Kebudayaan secara Linguistis. Yogyakarta: Duta Wacana University Press.

Sudjana, Nana. 2004. Dasar-dasar Proses Belajar Mengajar. Bandung: Sinar Baru Algensido Offset.

Sugiyono. 2011. Metode Penelitian Kombinasi(Mixed Methods). Bandung: Alfabeta. 2013. Metode Penelitian Pendidikan: Pendekatan Kuantitatif, Kualitatif dan $R \&$ D. Bandung: Alfabeta.

Sukhrani, Dewi. (2010). Leksikon Bahasa Gayo dalam Lingkungan Kedanauan Lut Tawar: Kajian Ekolinguistik. Jurnal Ilmiah Ilmu Bahasa. Tahun 7 Nomor 1. 40-57. ISSN 16934660. Medan: Ikatan Alumni Linguistik dengan Program Studi Linguistik SPs USU.

Sutarno. 2008. Pendidikan Multikultular. Bahan Ajar Cetak-Direktorat Jendral Pendidikan Tinggi Departemen Pendidikan Nasional. Jakarta.

Umiyati, Mirsa. (2011). Ketahanan Khazanah Lingual Pertanian Guyub Tutur Bahasa Bima dalam Persfektif Ekolinguistik Kritis. International Seminar "Language Maintenance and Shift" July 2, 2011. Master Program in Linguistics. Diponegoro University.

Wagiran. (2012). Pengembangan Karakter Berbasis Kearifan Lokal Hamemayu Hayuning Bawana (Identifikasi Nilai-nilai Karakter Berbasis Budaya). Jurnal Pendidikan Karakter, Tahun II, No. 3.

Wati, Erna. (2013). Leksikon Ekologi Kesungaian Lau Bingei: Kajian Ekolinguistik. Jurnal Metamorfosa. Volume 2. No.1 